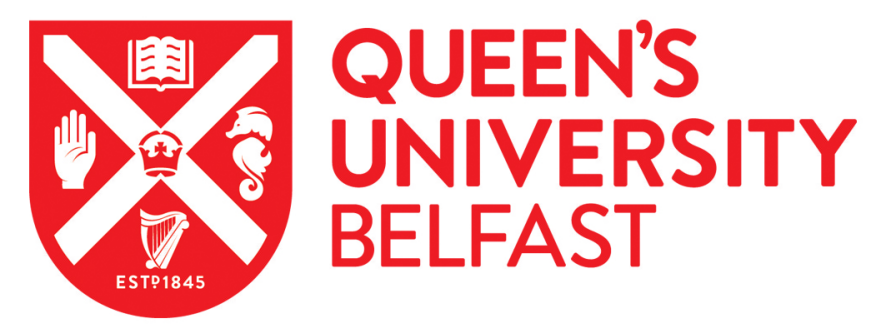

\title{
Settlement of Ostrea edulis is determined by the availability of hard substrata rather than its nature: implications for stock recovery and restoration of the European oyster
}

Smyth, D., Mahon, A. M., Roberts, D., \& Kregting, L. (2018). Settlement of Ostrea edulis is determined by the availability of hard substrata rather than its nature: implications for stock recovery and restoration of the European oyster. Aquatic Conservation Marine and Freshwater Ecosystems. https://doi.org/10.1002/aqc.2876

Published in:

Aquatic Conservation Marine and Freshwater Ecosystems

Document Version:

Peer reviewed version

Queen's University Belfast - Research Portal:

Link to publication record in Queen's University Belfast Research Portal

\section{Publisher rights}

Copyright Wiley 2017. This work is made available online in accordance with the publisher's policies. Please refer to any applicable terms of use of the publisher.

\section{General rights}

Copyright for the publications made accessible via the Queen's University Belfast Research Portal is retained by the author(s) and / or other copyright owners and it is a condition of accessing these publications that users recognise and abide by the legal requirements associated with these rights.

Take down policy

The Research Portal is Queen's institutional repository that provides access to Queen's research output. Every effort has been made to ensure that content in the Research Portal does not infringe any person's rights, or applicable UK laws. If you discover content in the Research Portal that you believe breaches copyright or violates any law, please contact openaccess@qub.ac.uk. 
Settlement of Ostrea edulis is determined by the availability of hard substrata rather than its nature: implications for stock recovery and restoration of the European oyster

David Smyth ${ }^{a *}$, Anne Marie Mahon ${ }^{b}$, Dai Roberts ${ }^{a}$ and Louise Kregting ${ }^{c}$

a School of Biological Sciences, Queen's University Belfast, 97 Lisburn Road, Belfast

b Galway-Mayo Institute of Technology, School of Science, Gaillimh, Co. Galway, Ireland

' School of Natural and Built Environment, Queen's University Belfast, Northern Ireland, United Kingdom

Current address: School of Natural and Built Environment, Queen's University Belfast, Northern Ireland, United Kingdom

\section{Abstract}

1. Since the collapse of the Ostrea edulis stock in the mid-1800s the oyster has struggled to re-establish itself in self-sustaining assemblages in Europe.

2. It is now widely recognized that $O$. edulis is an integral component of a healthy biologically functional benthic environment and as such, the restoration of wild stocks has become a matter of urgency.

3. A major limiting factor in $O$. edulis stock recovery is the availability of suitable substrate material for oyster larvae settlement.

4. This research re-examined the larval settlement potential of several naturally occurring in-situ shell materials (e.g. Mytilus edulis, Modiolus modiolus, O. edulis) with the aim of determining the most appropriate for large-scale restoration projects.

5. A positive correlation between available shell material and settlement was determined and analysis using PERMANOVA did not identify an attachment preference by $O$. edulis to any particular shell type.

6. The findings suggest that if restoration efforts were coordinated with applied hydrodynamic and habitat suitability modelling in conjunction with naturally occurring shell substrate concentrations, a cost-effective recovery for $O$. edulis assemblages in the wild could be achieved.

${ }^{*}$ Correspondence to David Smyth, School of Natural and Built Environment, Queen's University Belfast, Northern Ireland, United Kingdom. Email: D.M.Smyth@qub.ac.uk

KEY WORDS: bivalve, calcium carbonate, European oyster restoration, larval attachment, Mytilus edulis, Ostrea edulis. 


\section{INTRODUCTION}

The availability of substrate for sessile benthic animals during the settlement and attachment phases of life cycles is of significant importance because the opportunities to relocate after metamorphosis are limited (Padilla, 2010, 215; Walne, 1958, 597). The settlement phase for bivalve larvae is particularly important as they are unable to metamorphose successfully unless they are attached to a suitable substrate (Wieczorek \& Todd, 1998, 92). Bivalve species which adhere via a byssal thread tend to be less discerning in their substrate preference and can be found attached to metal, plastic, wood, and glass (Tamburri, Luckenbach, Breitburg \& Bonniwell, 2008, 606). Ostreidae in contrast are typically found attached to natural substrates rich in calcium carbonate such as shells and coralline algae (Fitt et al.,1990). However, occasionally larvae will attach themselves to artificial substrates such as glass, polystyrene and mylar polyester films. It has been shown that these attachments occur as a result of the substrate material being covered in marine bacteria notably two species; Alteromonas colwelliana and Shewanell colwelliana (Tamburri, Luckenbach, Breitburg \& Bonniwell, 2008, 607). These bacterial biofilms serve as a source of metabolites which act in conjunction with ammonia to elicit the settlement procedure (Fitt et al., 1990, 391).

Although bacterial films can induce attachment adults from the same species, emit the most effective chemical cues. Studies have shown that mature Ostreidae produce chemical signals which are conveyed by adult conspecifics and induce the settlement of larvae (Tamburri, Luckenbach, Breitburg \& Bonniwell, 2008, 606; Walne, 1958, 592). The concentrated release of these chemicals by adult conspecifics from oyster assemblages is the driver for dense gregarious localized settlements. If left undisturbed the live oyster substratum can form extensive beds and reefs (Kennedy, 1983, 328).

The gregarious settlement of larvae is of particular importance to broadcast spawning cementation bivalve species as the settlement process is limited to a period of 11-16 days (Cole \& Knight-Jones, 1939, 91). The density of oyster larvae attachment and the area of settlement coverage are primarily governed by the availability of suitable hard substratum (Marshall \& Dunham, 2013, 72). Therefore, any large-scale removal of live Ostreidae and dead shell material can result in the fragmentation of assemblages and the loss of future settlement areas for subsequent generations. It was the extensive large scale removal of live oysters and their shell debris which triggered the decline of $O$. edulis beds in Europe during the 1800s (Laing, Walker, \& Areal, 2006, 284).

The demise of $O$. edulis throughout Europe in the mid-1800s was a result of high consumer demand. In the UK port of Newhaven for example, approximately 20 million oysters were 
exported between 1834 and 1836 (Edwards, 1997, 87; Thurstan, Hawkins, Raby, \& Roberts, $2013,255)$. The custodians of the Firth of Forth oyster fishery in Scotland documented a further illustration of the intensity of exploitation during the early $1800 \mathrm{~s}$. The Firth beds covered an area $32.2 \mathrm{~km}$ long and $9.7 \mathrm{~km}$ wide and fishermen could dredge up to 6000 oysters in a single day. However, landings declined rapidly as fishing intensified prompting the Fishery Board of Scotland to conduct an investigatory dredge survey over the previously productive grounds in 1895. The survey revealed a catastrophic reduction in standing stock with an average of only four live oysters recorded in a single days dredging (Thurstan, Hawkins, Raby, \& Roberts, 2013, 259). As market demand for O. edulis grew so did the degree of overexploitation. The pressure placed on oyster fisheries was considerable, for example in 1864 approximately 700 million oysters were consumed in London alone (Edwards, 1997, 86). This level of consumption led to the classic overfishing scenario whereby market demand outweighed natural stock replenishment resulting in the total collapse of the fishery. As a consequence, UK annual landings fell from 3,500 tonnes in 1887 to 250 tonnes by 1947 (Edwards, 1997, 87; Laing, Walker, \& Areal, 2006, 285). O. edulis stocks in the UK have remained in a state of collapse since, with recent (1990-2010) annual landings for Ireland and the UK combined being no more than 200 tonnes (Jones, Dye, Pinnegar, Warren, \& Cheung, 2013, 719).

The plight of the European oyster, Ostrea edulis, has been widely acknowledged. It has been listed by the OSPAR Convention for the Protection of the Marine Environment of the NorthEast Atlantic as a threatened species in decline since 2003 (OSPAR Commission, 2009). The oyster was included within the remit of the UK Biodiversity Plan (UKBAP, 2009), from which the Native Oyster Species Action Plan (NOSAP) was developed. This encourages the maintenance and expansion of all existing $O$. edulis assemblages within UK inshore waters (Hiscock et al., 2013, 108). It was also listed as a priority marine species under the Review of Marine Nature Conservation UK in 2007 (Lieberknecht, Mullier, \& Ardron, 2014, 88). In England and Wales $O$. edulis has been accepted as a Feature of Conservation Importance $(\mathrm{FOCl})$ and in Scotland it has been recognized as a Priority Marine Feature (PMF) (Hirst, Clark, James, Kent, \& Loxton, 2012; Shucksmith,Gray, Kelly, \& Tweddle, 2014, 3). European and UK Governments along with private stakeholders have been actively assisting research into the restoration and recovery of $O$. edulis with several projects initiated in recent years, e.g. SETTLE, OYSTERCOVER, IBIS, SARF056, BLUE Solent, Mumbles Wales and NordOstron (Bostock, Lane, Hough, \& Yamamoto, 2016, 703; Gravestock \& James, 2014). All of these $O$. edulis restoration research programmes agree that successful natural recovery is dependent on a suite of factors; larval recruitment, local environmental conditions, hydrographic regime and most crucially the presence of suitable settlement substrate in 
particular adult shells or shell debris (Kennedy \& Roberts, 1999, 87; Smyth, Al-Maslamani, Chatting, \& Giraldes, 2016, 153).

The restrictions imposed because of low-density $O$. edulis larval recruitment have been reduced to some extent by the advances in hydrodynamic modelling. Oyster restoration stakeholders can now strategically position small, high-density brood-stock assemblages $(100,000)$ in locations whereby the maximum larval dispersal potential can be predicted and concentrated settlements accommodated (Kennedy \& Roberts, 1999, 83; Kregting \& Elsäßer, 2014, 60; Laing,Walker, \& Areal, 2006, 282;Smyth, Al-Maslamani, Chatting, \& Giraldes, 2016, 150). An example of low density brood-stock productivity was documented in Strangford Lough in 1997 when an oyster marketing company over-summered approximately 125,000 0. edulis on the low intertidal of the north western shore (Kennedy \& Roberts, 1999, 81). The oysters subsequently spawned and over a period of five years the progeny repopulated the entire northern basin to a standing stock of 1.2 million by 2003 (Kennedy \& Roberts, 2006, 156; Smyth, Roberts, \& Brown, 2009, 918). However, stocks had declined to 650,000 by 2005 due to un-regulated harvesting (Smyth, Roberts, \& Brown, 2009, 919). Natural recovery can be excluded as an explanation for the re-establishment of this stock as $O$. edulis had previously been considered functionally extinct within the lough (Briggs, 1978, 306; Nunn, 1992, 85). Furthermore molecular genetic evidence showed no differentiation among oyster samples derived from the aquaculture stock and the newly settled oysters (Kennedy \& Roberts, 2006, 156; Smyth, Roberts, \& Brown, 2009, 920).

Although low-density brood-stock stations and predictive dispersal modelling can overcome restrictions of oyster larval supply in restoration programmes the availability of shell as a settlement material remains a major limiting factor. Alternative substrate types have been trialled but success has been variable and the effort to prepare materials incredibly time consuming (Pioch,Kilfoyle, Levrel, \& Spieler, 2011, 258). To date, the most successful restoration programmes have incorporated shell cultch into settlement site substrates and include Indian River Lagoon Florida, Chesapeake Bay Maryland, South Carolina USA, the Billion Oyster Project New York City for Crassostrea virginica and Yerseke Bank Netherlands for O. edulis (Krasny, Crestol, Tidball, \& Stedmann, 2014,18; Sawusdee, Jensen, Collins, \& Hauton, 2015, 46).

However, the use of $O$. edulis shell cultch for restoration would not be feasible in the UK or other European countries primarily because of the lack of available shell, and thus alternative materials need to be identified (Trimble, Ruesink, \& Dumbauld, 2009, 104). Spat collection for aquaculture of $O$. edulis has been carried out for well over 100 years when limed plates were 
used as spat collectors (Cole \& Knight-Jones, 1939, 100; Herdman, 1903, 130) other materials used include cockle and mussel shells (Rodstrom, 2000, 802).

In an attempt to identify, the settlement and substrate preferences of $O$. edulis in the wild, field studies at both subtidal and intertidal sites were conducted amongst a recovering stock at Strangford Lough, Northern Ireland. The results of the investigation can be used to explain natural recovery and provide strategies for restoration without involving the costly deployment of specific shell type cultch.

\section{METHODS}

\section{Study area}

Strangford Lough is located on the northeast coast of Ireland and lies between $54^{\circ} 35^{\prime} \mathrm{N}$ and $54^{\circ} 20^{\prime} \mathrm{N}$ and between $5^{\circ} 41^{\prime} \mathrm{W}$ and $5^{\circ} 34^{\prime} \mathrm{W}$ (Figure 1) enclosing an area of $150 \mathrm{~km}^{2}$. The depth of the lough ranges from 14-60 $\mathrm{m}$, with substrate varying from bedrock to fine sediments winnowed out by a gradient of tidal water movement (Erwin, 1978). The lough can be divided into northern and southern basins (Figure 1). The tidal currents are weak in the north basin and soft mud deposits are characteristic in comparison to the central region of the channel where a shell mix biotope on top of fine mud is dominant. The entrance to the south basin is a long narrow channel known as the Narrows where current tidal velocity reaches $\sim 3.5 \mathrm{~m} / \mathrm{s}$ (Kregting \& Elsäßer, 2014, 62) and is typified by an exposed bedrock substratum (Kregting et al., 2016, 11) which spills out into the south basin where a range of substrates can be found depending on water flow velocity.

\section{Site selection}

Site selection was based on results from previous stock density and larval settlement surveys within Strangford Lough (Kennedy \& Roberts,1999, 80; Kennedy \& Roberts, 2006, 154; Smyth $\&$ Roberts, 2010, 27). To ascertain if oyster larvae showed a settlement preference in relation to substrate type it was essential to select high-density oyster sites with a wide variety of naturally available substrates. In previous studies (Briggs, 1978, 311; Kennedy \& Roberts, $1999,81 ; 2006,155)$ four sites with a variety of substrates constantly revealed high densities

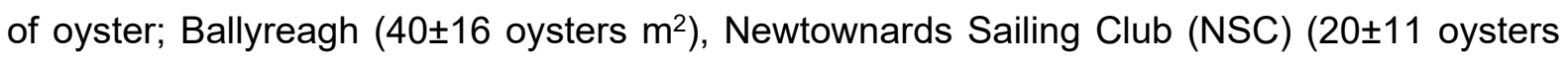
$\mathrm{m}^{2}$ ), Greyabbey $\left(20 \pm 9\right.$ oysters $\mathrm{m}^{2}$ ) and Ringhaddy (22 \pm 7 oysters $\mathrm{m}^{2}$ ) (Figure 1$)$. Ringhaddy was the only subtidal location surveyed where densities $\left(22 \pm 7\right.$ oyster's $\left.\mathrm{m}^{2}\right)$ and substrate variants were comparable (Figure 1). 


\section{Available Substrate Types}

Surveys took place over a five-year period from June 2005 to June 2010. A method of continuous random deployment of gridded $0.25 \mathrm{~m}$ quadrats in an expanding square formation was carried out to ensure that the percentage cover of substrate and oyster densities were uniform amongst all sites. This resulted in the following plot area allocations: Ballyreagh $10 \mathrm{x}$ $5 \mathrm{~m}^{2}$, NSC $10 \times 5 \mathrm{~m}^{2}$, Greyabbey $10 \times 10 \mathrm{~m}^{2}$ and Ringhaddy Sound $20 \times 3 \mathrm{~m}^{2}$. Substratum composition was documented in-situ by taking digital still photographs of 25 randomly placed $0.25 \mathrm{~m}$ quadrats. The images were assessed for percentage cover of substrate types based on a random 100 point quadrat methodology as per (Terlizzi, Anderson, Fraschetti, \& Benedetti-Cecchi, 2007, 28).

\section{Ostrea edulis sampling}

In order to minimize environmental impact, sampling took place over a five-year period on the, $10 / 2 / 2005,1 / 12 / 2005,9 / 10 / 2006,25 / 11 / 2009$, and 5/6/2010. Survey plot perimeters were marked by stakes at each corner to ensure sample collection accuracy was maintained throughout. Transect lines were laid diagonally between plot corners before each sampling effort. A $0.25 \mathrm{~m}$ quadrat was used to randomly sample either side of both transect lines. Approximately 20 adult $O$. edulis were collected until 160 oysters were collected from each site during the sampling period. The 480 oysters from the intertidal sites could be separated into four age and size cohorts as per Richardson et al., (1993); 72 x 20-40 mm (2-3yr), 168 x 40-60 mm (2-4yr), 192 x 60-80 mm (4-6yr) and 48 x 80-100 mm (8-12yr). The 160 subtidal oysters could be divided into only two age and size cohorts; 88 x 60-80 mm (4-6yr) and $72 \mathrm{x}$ 80-100 mm (8-12yr). All oysters were returned to the laboratory where the left valve of each was examined using a Nikon ${ }^{\odot} S M Z 400$ stereomicroscope to identify the remnants of the settlement substrate.

\section{Data analysis}

To investigate if a shell type preference was apparent during the attachment of $O$. edulis a range of analyses were applied using PRIMER $6.0^{\circ}$ with PERMANOVA addition and PAST $3.14^{\odot}$ software. A Bray-Curtis similarity matrix was used throughout the PERMANOVA analysis with 9999 permutations to determine the similarities of square-root transformed data on all four sites in relation to \% coverage of substrate type and \% oyster attachment to substrate type.

A Multidimensional Dimensional Scaling (MDS) programme then subjected the data to 2dimensional ordination. In MDS, the Bray-Curtis coefficients between each pair of sites were used to produce a plot showing all relationships. A "Stress" value for the plot is produced and is displayed in the top right hand corner of the plot. When a stress value is $<0.05$ it is 
considered an excellent expression, 0.1 is regarded as a good representation but values between 0.1 and 0.2 are still useful (Clarke \& Warwick, 2001, 172). SIMPER analysis was employed to determine the settlement substrates responsible for the differences within the average Bray-Curtis similarity coefficients between the sites. Essentially this procedure computes the average dissimilarity between all pairs of the inter-group locations, and then breaks down the average into separate contributions from each substrate type to which the oyster has settled on (Clarke \& Warwick, 2001,172).

A PERMANOVA was then carried out on the most statistically significant matrices identified with SIMPER to determine if attachment preference could be assigned to a specific shell type. $\mathrm{PAST}^{\odot} 3.14$ was used to investigate the relationship between substrate coverage and oyster attachment substrate by means of a linear regression model using the pooled data from all four sites.

\section{RESULTS}

Percentage substrate type cover showed a highly significant difference between sites (PERMANOVA Pseudo $F=18.01, p=0.0001$ ). Pairwise post-hoc analysis (Table 1 ) revealed Ringhaddy was significantly different $(p<0.0005)$ from all three intertidal sites. Substrate coverage at the northerly intertidal site of Ballyreagh (Figure 1 ) was significantly different from Newtownards Sailing Club (NSC) $(p<0.005)$ but not Greyabbey.

Percentage oyster attachment to substrate type identified a highly significant difference between sites (PERMANOVA: Pseudo $\mathrm{F}=6.72, p=0.0001$ ). Pairwise post-hoc analysis (Table $2)$ revealed that the subtidal site at Ringhaddy was highly significantly different $(p<0.0005)$ from all three intertidal sites. Ballyreagh was significantly different from NSC $(p<0.05)$ but no difference was detected with Greyabbey. No significant differences were identified between Greyabbey and the other two intertidal sites (Table 2).

A plotted orientation of the differences between settlement substrate similarities and available $\%$ cover for each site are presented in a non-parametric MDS plot (Figure 2). The analysis produced a stress value of 0.18 , which is considered a useful assessment of similarities. A clear grouping was seen within the Ringhaddy settlement substrate types. A grouping of similarities between settlement substrates was also revealed between NSC and Greyabbey. Ballyreagh had five outlying samples when compared to NSC and Greyabbey. Comparison of $\%$ oyster attachment in relation to \% cover of available settlement substrate for each site revealed Mytilus edulis to be the most abundant $\mathrm{CaCO}_{3}$ substrate at all intertidal sites (Figure 3). At Ballyreagh $M$. edulis accounted for $58 \%$ coverage, while at Greyabbey it constituted 
$46 \%$ and $16 \%$ at NSC. Subsequently the highest percentage of attachment within the oyster cohorts sampled at these intertidal sites was on $M$. edulis. At Ringhaddy, the highest attachment $\%$ on shell was O. edulis (24\%) (Figure 3$)$.

SIMPER analysis revealed that the highest density of oyster attachment was on the shell of M. edulis at the three intertidal sites. The majority of substrate attachments could not be identified on oysters from the subtidal site and were therefore labelled as unknown. Results showed that site location and the available substrate type influenced what the oysters attached to. The average intra-site similarities between settlement material and oyster attachment showed a high \% of similarity between $M$. edulis, $O$. edulis and unknown, the three most common attachment categories (Table 3).

Average (av.) dissimilarity (dis) of 36.66 was recorded between oyster attachment substrate for Ballyreagh and Greyabbey, and 34.30 for Ballyreagh and NSC. The comparison between Greyabbey and Ringhaddy revealed an av. dis. of 36.44 and between NSC and Ringhaddy was shown to be 39.14. The highest av. dis. of attachment categories and site was between Ballyreagh and Ringhaddy with 49.95 (Table 4). The lowest av. dis. recorded was between Greyabbey and NSC 28.94. The substrate attachment categories which differed most in frequency between sites were: Unknown, Modiolus modiolus, Pecten maximus, Mimachlamys varia, and pebble (Table 4).

PERMANOVA analysis of the most significant matrices from the SIMPER analyses of intersite substrate attachment revealed a highly significant difference (Pseudo $\mathrm{F}=6.72, p=0.0001$ ) between the four sites in relation to oyster attachment onto $M$. edulis and $O$. edulis. Post-hoc pairwise analysis showed Greyabbey and Ringhaddy to be significantly different $(p<0.05, p<$ 0.0005); however, no significant differences were detected between Ballyreagh and NSC (Table 5).

To test if either $M$. edulis or $O$. edulis shell types had an influence on $\%$ oyster attachment a PERMANOVA was carried out between \% coverage and oyster attachment for the three intertidal sites. Ringhaddy, the subtidal site, was excluded from the analysis as $M$. edulis was not recorded during the surveys no significant difference was detected (Pseudo $\mathrm{F}=0.762, p=$ $>0.5$ ). A linear regression model for pooled data from all four sites to investigate the relationship between shell substrate and oyster attachment revealed a strong positive correlation $\left(R^{2}=0.94\right)$ between shell availability and percentage of attachment (Figure 4). 


\section{DISCUSSION}

The economic value of the European flat oyster Ostrea edulis has led to a number of studies into the settlement of its larvae onto a variety of substrates within an aquaculture hatchery focused environment (Carnegie, Arzul, \& Bushek, 2016, 2015; Lallias, Boudry, Lapague, King, \& Beaumont, 2010, 1907; Maneiro, Prez-Parall, Silva, Sanchez, \& Pazos, 2017, 3; MesíasGansbiller et al., 2013, 6; Zhao, Zhang, \& Qian, 2003, 885). However, there have been relatively few investigations into this aspect of its life cycle in the wild since those of (Cole \& Knight-Jones, 1939), Waugh (1972) and (Hidu \& Valleau, 1979). The current study represents one of the only recent in-situ investigations into the attachment preferences of $O$. edulis over a suite of naturally occurring settlement materials both intertidally and subtidally.

The study identified the highest density of shell substrate available at the intertidal sites as being $M$. edulis and at the subtidal site $O$. edulis (Figure 3 ). The findings are comparable to those documented by (Cole \& Knight-Jones, 1939) particularly the data from the Ballyreagh site (Tables 1 and 2). (Cole \& Knight-Jones, 1939) showed wild O. edulis from the Helford River, Cornwall settled in their highest densities on living clumps of blue mussels, the next most concentrated settlements were on empty valves of $M$. edulis. They concluded that in the absence of living or dead $O$. edulis shell that $M$. edulis offered the most favourable alternative to settling $O$. edulis larvae. This was also apparent within the current research (Table 3). Barry (1981) confirmed $M$. edulis as a settlement substrate at Kilkienan and Bertraghboy Bays, Connemara, Ireland when it was reported that large numbers of oyster spat $(>78)$ were attached to single mussel valves. $M$. edulis shells were used the following year as a cultching material on barren mud substrates within the bays and as a result spat settlement increased by $>40 \%$. Waugh (1972) also revealed that in the River Fal O. edulis larvae could settle equally well on several shell substrata in the absence of shell of its own species. This study concurred with Waugh (1972) as no preference for a specific shell type was detected. Instead, larval attachment appeared to be governed by the amount of available shell substrate and not shell type (Figure 4).

The subtidal, site at Ringhaddy revealed the most abundant settlement substrate category to be 'unknown' (Figure 3) as no remnant of the original attachment substrate could be identified. A hydrodynamic model of Strangford Lough shows that on flooding and ebbing tides the subsurface currents experienced at this site can be considerable $\left(0.5 \mathrm{~m} \mathrm{~s}^{-1}\right)$ (Kregting \& Elsäßer, 2014, 62). Attachment material on the Ringhaddy oysters could therefore, have been removed through abrasive action against the seabed over the tidal cycles. Previous settlement studies of subtidal oysters in the wild have also recorded a similar high proportion of nonidentifiable attachment substrate (Barry, 1981; Cole \& Knight-Jones, 1939, 93). (Gubbay \& 
Knapman, 1999) noted that raking and turning during commercial cultivation caused abrasive actions which damaged oysters, reducing the value of the crop.

In contrast to Ringhaddy the intertidal site at Ballyreagh experiences a low tidal velocity (Kregting \& Elsäßer, 2014) and is characterized by large M. edulis beds. The differing hydrodynamic parameters which occur at these two locations ensure a high degree of variation between biological characteristics and available substrate type (Smyth, Kregting, Elsäßer, Kennedy, \& Roberts, 2016, 56). The sites at Greyabbey and NSC displayed the lowest average dissimilarity between oyster attachment preference (Tables 2 and 3). These two sites experience similar hydrodynamic conditions (Kregting and Elsäßer, 2014, 60) which in-turn governs substratum type and larval settlement densities.

Three major techniques for oyster stock management and restoration are translocation, harrowing and deployment of cultch. For over 200 years millions of $O$. edulis have been translocated to introduce the species to areas where it had not previously occurred or to augment failing oyster fisheries (Bromley, McGonigle, Ashton, \& Roberts, 2016a, 106). Introductions to new areas have had mixed results with many translocations intended for stock augmentation resulting in "put and take" fisheries (Bromley, McGonigle, Ashton, \& Roberts, $2016 \mathrm{~b}, 163)$. Harrowing old oyster beds, which are no longer sustainable aims to expose clean shell material on which benthopelagic larvae can settle. It is a widely advocated but poorly studied strategy to restore degraded oyster habitat but is not suitable for all populations of $O$. edulis and should be used with caution (Bromley, McGonigle, Ashton, \& Roberts, 2016b, 162). Cultch has been widely used for oyster habitat restoration, most successfully for Crassostrea virginica in the USA, particularly where conspecific shells have been used as cultch and relaid in high relief reefs (Nestlerode, Luckenbach, \& O'Brien, 2007, 274). However, limited availability of oyster shell cultch to create large-scale reefs has resulted in the widespread use of other cultch materials such as shells of the surf clam, Spisula solidissima. Comparison of performance of both cultch materials revealed that reefs constructed from oyster shells supported greater oyster growth and survival and offered the highest degree of structural complexity than those constructed from Spisula shells (Nestlerode, Luckenbach, \& O'Brien, 2007,281 ). Over 80 years ago it was suggested that in ostreids the best settlement substrate for conspecific larvae is the clean growth rim of the shell (Galstoff \& Luce, 1930) which resulted in high-density, self-perpetuating oyster beds. However, because of historical overfishing in Europe insufficient quantities of $O$. edulis shells are no longer locally available to support parent shell stock restoration programmes. In addition, EU and local regulations prohibit the deployment of non-indigenous substrates to prevent inter-site translocation of pests and diseases with shell cultch. The results of the present study show that $M$. edulis is a viable alternative to $O$. edulis parent shell in the wild. The culture of blue mussels is widespread in 
Europe with minimal crop attention required and relatively quick growth to marketable size (Bethel et al., 2011, 560). Therefore, the blue mussel offers potential O. edulis restoration programmes a source of cultch which could be generated as a by-product of mussel aquaculture and used in the same locality thus avoiding the need to import cultch. This approach is already in practice at Sungo Bay, Shangdong Peninsula China. At Sungo Bay, suspended aquaculture systems for $M$. edulis are maintained to enhance naturally existing stocks of the mussel not only as an artisanal fishery resource but also as a means of habitat enrichment. The excess $M$. edulis provide a hard substratum on soft muds for more influential bioengineering species such as Crassostrea rivularis (Bethel et al., 2011, 569; Selkoe et al., 2015). Offshore culturing of $M$. edulis is currently underway with the same objectives in France, Germany, Netherlands, the USA, New Zealand and Japan. These ventures provide both an economic resource and a substrate enhancement material (Whitmarsh, Cook, \& Black, 2006, 295; Navarrete-Mier, Sanz-Lázaro, \& Marin, 2010, 103). The systems employed in these offshore programmes require minimal maintenance and produce greater tonnages of meat and shell than coastal operations (Dame, 2011; Poe et al., 2014).

Although a number of recent studies emphasize the importance of restoring oyster derived ecosystem services such as water column filtration, benthic-pelagic coupling and substrate stability (Dame, 2011; Thurstan, Hawkins, Raby, \& Roberts, 2013, 260; Smyth, Kregting, Elsäßer, Kennedy, \& Roberts, 2016, 56) most oyster stock management and restoration efforts have commercial objectives. (Laing, Walker, \& Areal, 2006, 285) described a Cost Benefit Analysis (CBA) associated with $O$. edulis restoration and showed that the non-marketable costs and benefits provide high value (e.g. biodiversity, environmental services) even if the oysters are non-marketable. In addition, when restoration is practised within protected areas there is good evidence that spill-over recruitment will populate adjacent areas open for fishing (Cranfield, Michael, \& Doonan,1999, 480).

However, the opening of an active fishery should carried out with caution, as the impact of unsustainable exploitation over a period of time can be severe with many heavily fished sites never fully recovering (Cranfield, Michael, \& Doonan,1999, 462; Lallias, Boudry, Lapague, King, \& Beaumont, 2010, 1907). This scenario of restoration and demise has led to a number of authors questioning whether the costs of oyster restoration are justified. For example, projects to restore the native oyster (Crassostrea virginica) in the Chesapeake Bay area attract enormous public support but have consumed vast, arguably unreasonable, amounts of funding, yet quantitative approaches used successfully in the restoration of other marine and estuarine species have not been appropriately applied (Kransy, Crestol, Tidall, \& Stedman, $2014,21)$. The most pervasive obstacle to successful management and restoration of oyster 
resources is that many managers and stakeholders deny that a problem exists (Laing, Walker, \& Areal, 2006, 284).

In conclusion, as oyster numbers decline throughout the world and environmental legislation increases, pressure will also increase on government departments to maintain and conserve native species. The attachment results recorded during the investigation agree with (Waugh,1972) hypothesis that $O$. edulis spat will settle equally well on a number of shell substrata and that there is a direct correlation between available settlement substrata and oyster densities. Thus, the use of cultch may be an unnecessary costly intervention when the experiences in Mobile Bay, USA, Tasman Bay, Australia and Strangford Lough, Northern Ireland are considered. A more promising approach, which would apply to all species of oyster involves; the application of hydrodynamic and habitat suitability modelling supported by field validation to identify areas where re-laid, high-density oysters would act as a source of larvae. These in-turn would settle in sink areas thus accelerating the recovery and restoration of oyster communities (Broekhuizen, Lundquist, Hadfield, \& Brown, 2011, 655; Kim, Park, \& Powers, \& 2013, 360; Smyth, Kregting, Elsäßer, Kennedy, \& Roberts, 2016, 57).

\section{ACKNOWLEDGEMENTS}

This work was funded by the Departments of Employment and Learning, and Agriculture and Rural Development (EU Building Sustainable Development Programme) Northern Ireland. D. Smyth was also supported by a special award from the Worshipful Company of Fishmongers, London which enabled him to complete diving training to conduct sublittoral surveys. We are particularly grateful to the staff of Queen's University Centre for Marine Resources and Mariculture.

\section{REFERENCES}


Barry, M. (1981). Distribution and ecology of oysters, Ostrea edulis (L.) in Kilkieran and Bertraghboy Bays, Connemara, Co. Galway. Irish Fisheries Investigations Series B, Departmentof Agriculture and Fisheries.

Bethel, M.B., Brien, L.F., Danielson, E.J., Laska, S.B., Troutman, J.P., Boshart, W.M., Giardino, M.J., \& Phillips, M.A. (2011). Blending Geospatial Technology and Traditional Ecological Knowledge to Enhance Restoration Decision-Support Processes in Coastal Louisiana. Journal of Coastal Research, 27, 555-571.

Bostock, J., Lane, A., Hough, C., \& Yamamoto, K. (2016). An assessment of the economic contribution of EU aquaculture production and the influence of policies for its sustainable development. Aquaculture International, 24, 699-733.

Briggs, R.P., (1978). Aspects of oyster culture in Strangford Lough, Northern Ireland. Aquaculture, 15, 307-318.

Broekhuizen, N., Lundquist, C.J., Hadfield, M.G., Brown, S.N., \& Brown, S.N. (2011). Dispersal of Oyster ( Ostrea chilensis ) Larvae in Tasman Bay Inferred using a Verified Particle Tracking Model that Incorporates Larval Behavior, Journal of Shellfish Research. 30, 643-658.

Bromley, C., McGonigle, C., Ashton, E.C., \& Roberts, D. (2016a). Bad moves: Pros and cons of moving oysters - A case study of global translocations of Ostrea edulis Linnaeus, 1758 (Mollusca: Bivalvia). Ocean and Coastal Management, 122, 103-115.

Bromley, C., Mcgonigle, C., Ashton, E.C., \& Roberts, D. (2016b). Restoring degraded European native oyster, Ostrea edulis, habitat: is there a case for harrowing? Hydrobiologia, 768, 151-165.

Brumbaugh, R.D., \& Coen, L.D. (2009). Contemporary approaches for small-scale oyster reef restoration to address substrate versus recruitment linitation: A review and comments relevant for the Olympia oyster; Ostrea lurida Carpenter 1864. Journal of Shellfish Research, 28, 147-161.

Carnegie, R.B., Arzul, I., \& Bushek, D. (2016). Managing marine mollusc diseases in the context of regional and international commerce: policy issues and emerging concerns. Philosophical Transactions of the Royal Society B: Biological Sciences, 371, 2015.

Clarke, K.R., \& Warwick, R.M. (2001). Change in marine communities: an approach to statistical analysis and interpretation, 2nd edition. PRIMER-E, Plymouth UK, p.172.

Cole, H.A., \& Knight-Jones, E.W. (1939). Some observations and experiments on the 
settling behavior of Ostrea edulis. ICES Journal of Marine Science, 14, 86-105.

Cranfield, H.J., Michael, K.P., \& Doonan, I.J. (1999). Changes in the distribution of epifaunal reefs and oysters during 130 years of dredging for oysters in Foveaux Strait, southern New Zealand. Aquatic Conservation: Marine and Freshwater Ecosystems, 9, 461-483.

Dame, R.F. (2011). Ecology of marine bivalves: an ecosystem approach. CRC Press Taylor\& Francis.

Edwards, E. (1997). Molluscan fisheries in Britain. In Noaa Technical report Nmfs Noaa, pp. 85-100.

Erwin, D. (1978). Biology of Benthic Organisms: 11th European Symposium on Marine Biology (POC B. F. Keegan, P. J. S. Boaden, Ed).

Fitt, W.K., Coon, S.L., Walch, M., Weiner, R.M., Colwell, R.R., \& Bonar, D.B. (1990). Settlement behavior and metamorphosis of oyster larvae (Crassostrea gigas) in response to bacterial supernatants. Marine Biology, 106, 389-394.

Galstoff, P.S., \& Luce, R.H. (1930). Oyster investigations in Georgia. Bulletin of Burmese Fisheries, 46, 197-263.

Gravestock, V., \& James, F.G.M. (2014). Solent Native Oyster (Ostrea edulis) Restoration. MacAlister, Elliott \& Partners.

Gubbay, S., \& Knapman, P.A. (1999). A review of the effects of fishing within UK European marine sites. English Nature Peterborough. p.134.

Herdman, W.A., \& Hornell, J.H. (1903).Observations and experiments on the life-history and habits of the pearl oyster. Report. Pearl Oyster Fishery Gulf of Manaar, Royal Society of London, pp. 125-146.

Hidu, H., Valleau, W.G., \& Veitch F. (1979). Gregarious setting in European and American oysters: response to surface chemistry vs. waterborne pheromones. Proceedings of the National. Shellfish Association, 68, 11-16.

Hirst, N.E., Clark, L., \& Sanderson, W.G. (2012). The distribution of selected MPA search features and Priority Marine Features of the NE coast of Svcotland. Scottish Natural Heritage Commisioned Report 500. Edinbrugh: Scottish Natural Heritage, p.132.

Hiscock, K., Bayley, D., Pade, N., Lacey, C., Cox, E., \& Enever, R. (2013). Prioritizing action for recovery and conservation of marine species: A case study based on species of conservation importance around England. Aquatic Conservation: Marine and 
Freshwater Ecosystems, 23, 88-110.

Jones, M.C., Dye, S.R., Pinnegar, J.K., Warren, R., \& Cheung, W.W.L.( 2013). Applying distribution model projections for an uncertain future: The case of the Pacific oyster in UK waters. Aquatic Conservation: Marine and Freshwater Ecosystems, 23, 710-722.

Kennedy, R.J., \& Roberts, D. (1999). A survey of the current status of the flat oyster Ostrea edulis in Strangfod Lough, Northern Ireland, with a view to the restoration of its oyster beds. Biology and Environment: Proceedings of the Royal Irish Academy, 99B, 79-88.

Kennedy, R.J., \& Roberts, D. (2006). Commercial oyster stocks as a potential source of larvae in the regeneration of Ostrea edulis in Strangford Lough, Northern Ireland. Journal of the Marine Biological Association of the UK, 86, 153-159.

Kennedy, V. (1983). Sex-ratios in oysters, emphasising Crassostrea virginica from Chesapeake Bay, Maryland. Veliger, 25, 329-328.

Kim, C., Park, K., \& Powers, S.P. (2013). Establishing Restoration Strategy of Eastern Oyster via a Coupled Biophysical Transport Model, 21, 353-362.

Krasny, M.E., Crestol, S.R., Tidball, K.G., \& Stedman, R.C. (2014). New York City's oyster gardeners: Memories and meanings as motivations for volunteer environmental stewardship. Landscape and Urban Planning, 132, 16-25.

Kregting, L., \& Elsäßer, B. (2014). A Hydrodynamic Modelling Framework for Strangford Lough Part 1: Tidal Model. Journal of Marine Science and Engineering, 2, 46-65.

Kregting, L., Elsaßer, B., Kennedy, R., Smyth, D., O'Carroll, J., \& Savidge, G. (2016). Do changes in current flow as a result of arrays of tidal turbines have an effect on benthic communities? PLOS ONE, 11, 1-14.

Laing, I., Walker, P., \& Areal, F. (2006). Return of the native - is European oyster (Ostrea edulis) stock restoration in the UK feasible? Aquatic Living Resources, 19, 283-287.

Lallias, D., Boudry, P., Lapague, S., King, J., \& Beaumont, A. (2010). Strategies for the retention of high genetic variability in European flat oyster (Ostrea edulis) restoration programmes. Conservation Genetics, 11, 1899-1910.

Lieberknecht, L., Mullier, T., \& Ardron, J. (2014). Assessment of the ecological coherence of the UK' s marine protected area network. Areport prepared for the joint links, p. 88.

Maneiro, V., Perez-Paralle, M., Silva, A., Sanchez, J., \& Pazos, A. (2017). Conditioning of the European flat oyster (Ostrea edulis, Linnaeus 1758): Effect of food ration. 
Aquaculture Research, 1-8.

Marshall, R.D., \& Dunham, A. (2013). Effects of culture media and stocking density on biofouling, shell shape, growth, and survival of the Pacific oyster (Crassostrea gigas) and the Manila clam (Venerupis philippinarum) in suspended culture. Aquaculture, 406, 68-78.

Mesías-Gansbiller, C., Silva, A., Maneiro, V., Pazos, A., Sánchez, J.L., \& Pérez-Parallé, M.L. (2013). Effects of chemical cues on larval settlement of the flat oyster (Ostrea edulis L.): A hatchery approach. Aquaculture, 376, 85-89.

Navarrete-Mier, F., Sanz-Lázaro, C., \& Marín, A. (2010). Does bivalve mollusc polyculture reduce marine fin fish farming environmental impact? Aquaculture, 306, 101-107.

Nestlerode, J., Luckenbach, M. W., \& O'Beirn, F. (2007). Settlement and Survival of the OysterCrassostrea virginica on Created OysterReef Habitats in Chesapeake Bay. Restoration Ecology, 15, 273-283.

Nunn, J. (1992). The marine mollusca of Ireland 1 Strangford Lough. Bulletin of the Irish Biogeographical Society, 23-122.

OSPAR Commision. (2009). Background document for Ostrea edulis and Ostrea edulis beds. Report to the Covention for the Protection of the Marine Environment of the NortEast Atlantic, p. 22.

Padilla, D.K. (2010). Context-dependent impacts of a non-native ecosystem engineer, the pacific oyster crassostrea gigas. Integrative and Comparative Biology, 50, 213-225.

Pioch, S., Kilfoyle, K., Levrel, H., \& Spieler, R. (2011). Green Marine Construction. Journal of Coastal Research, 257-268.

Poe, M.R., Norman, K.C., \& Levin, P.S. (2014). Cultural dimensions of socioecological systems: Key connections and guiding principles for conservation in coastal environments. Conservation Letters 7, 166-175.

Richardson, C.A, Collis, S.A., Ekaratne, K., Dare, P., \& Key D. (1993). The age determination and growth rate of the European flat oyster, Ostrea edulis, in British waters determined from acetate peels of umbo growth lines. ICES Journal of Marine Science 50, 493-500.

Rodstrom, E.M., \& Jonsson, P.R. (2000). Survival and feeding activity of oyster spat (Ostrea edulis $L$ ) as a function of temperature and salinity with implications for culture policies 
on the Swedish west coast. Journal of Shellfish Research 19, 799-808.

Sawusdee, A., Jensen, A.C., Collins, K.J., \& Hauton, C. (2015). Improvements in the physiological performance of European flat oysters Ostrea edulis (Linnaeus, 1758) cultured on elevated reef structures: Implications for oyster restoration. Aquaculture $444,41-48$.

Schulte, D.M., Burke, R., \& Lipcius, R. (2009). Unprecedented Restoration of a Native Oyster Metapopulation. Science, 325, 1124-1128.

Selkoe, K.A., Blenckner, T., Caldwell, M.R., Crowder, L.B., Erickson, A.L., Essington, T.E., Estes, J.A., ... Hunsicker, M.E. (2015). Principles for managing marine ecosystems prone to tipping points. Ecosystem Health and Sustainability, 1, 1-18.

Shucksmith, R., Gray, L., Kelly, C., \& Tweddle, J.F. (2014). Regional marine spatial planning - The data collection and mapping process. Marine Policy, 50, 1-9.

Smyth, D., \& Roberts, D. (2010). The European oyster (Ostrea edulis) and its epibiotic succession. Hydrobiologia, 655, 25-36.

Smyth, D., Roberts, D., \& Browne, L. (2009). Impacts of unregulated harvesting on a recovering stock of native oysters (Ostrea edulis). Marine Pollution Bulletin, 58, 916 922.

Smyth, D., Al-Maslamani, I., Chatting, M., \& Giraldes, B. (2016). Benthic surveys of the historic pearl oyster beds of Qatar reveal a dramatic ecological change. Marine Pollution Bulletin, 113, 147-155.

Smyth, D., Kregting, L., Elsäßer, B., Kennedy, R., \& Roberts, D. (2016). Using particle dispersal models to assist in the conservation and recovery of the overexploited native oyster (Ostrea edulis) in an enclosed sea lough. Journal of Sea Research, 108, 50-59.

Tamburri, M. N., Luckenbach, M. W., Breitburg, D. L., \& Bonniwell, S.M. (2008). Settlement of Crassostrea ariakensis Larvae: Effects of Substrate, Biofilms, Sediment and Adult Chemical Cues. Journal of Shellfish Research, 27, 601-608.

Terlizzi, A., Anderson, M.J., Fraschetti, S., \& Benedetti-Cecchi L. (2007). Scales of spatial variation in Mediterranean subtidal sessile assemblages at different depths. Marine Ecology Progress Series, 332, 25-39.

Thurstan, R.H., Hawkins, J.P., Raby, L., \& Roberts, C.M. (2013). Oyster (Ostrea edulis) extirpation and ecosystem transformation in the Firth of Forth, Scotland. Journal for 
Nature Conservation, 21, 253-261.

Trimble, A.C., Ruesink, J.L., \& Dumbauld, B.R. (2009). Factors Preventing the Recovery of a Historically Overexploited Shellfish Species, Ostrea lurida Carpenter 1864. Journal of Shellfish Research, 28, 97-106.

UKBAP. (2009). Native oyster (Ostrea edulis) species action plan. UK biodiversity group. 241-242.

Walne, P.R. (1958). Growth of oysters (Ostrea edulis L.). Journal of the Marine Biological Association of the United Kingdom, 37, 591-602.

Waugh, G. (1972). Settlement of Ostrea edulis (L.), in relation to the cultivation of oyster grounds. Ministry of Agriculture, Fisheries and Food Great Britain.

Whitmarsh, D.J., Cook, E.J., \& Black, K.D. (2006). Searching for sustainability in aquaculture: An investigation into the economic prospects for an integrated salmonmussel production system. Marine Policy, 30, 293-298.

Wieczorek, S.K., \& Todd, C.D. (1998). Inhibition and facilitation of settlement of epifaunal marine invertebrate larvae by microbial biofilm cues. Biofouling, 12, 81-118.

Zhao, B., Zhang, S., \& Qian, P.Y. (2003). Larval settlement of the silver- or goldlip pearl oyster Pinctada maxima (Jameson) in response to natural biofilms and chemical cues. Aquaculture, 220, 883-901. 
Table 1. Pairwise post-hoc analysis between sites and \% shell substrate type cover $\mathrm{m}^{-2}$. Bold text highlights $p$ values with a statistical significant difference.

\begin{tabular}{l|llll} 
Site & Ballyreagh & NSC & Greyabbey & Ringhaddy \\
\hline Ballyreagh & & $\mathbf{0 . 0 0 1 2}$ & 0.1048 & $\mathbf{0 . 0 0 0 2}$ \\
NSC & $\mathbf{0 . 0 0 1 2}$ & & $\mathbf{0 . 0 3 3 8}$ & $\mathbf{0 . 0 0 0 2}$ \\
Greyabbey & 0.1048 & $\mathbf{0 . 0 3 3 8}$ & & $\mathbf{0 . 0 0 4}$ \\
Ringhaddy & $\mathbf{0 . 0 0 0 2}$ & $\mathbf{0 . 0 0 0 2}$ & $\mathbf{0 . 0 0 0 4}$ & \\
\hline
\end{tabular}

Table 2. Pairwise post-hoc analysis between sites and \% oyster attachment to shell substrate type. Bold text highlights $p$ values with a statistical significant difference.

\begin{tabular}{l|llll} 
Site & Ballyreagh & NSC & Greyabbey & Ringhaddy \\
\hline Ballyreagh & & $\mathbf{0 . 0 2 1}$ & 0.085 & $\mathbf{0 . 0 0 0 3}$ \\
NSC & $\mathbf{0 . 0 2 1}$ & & 0.203 & $\mathbf{0 . 0 0 0 3}$ \\
Greyabbey & 0.085 & 0.203 & & $\mathbf{0 . 0 0 0 4}$ \\
Ringhaddy & $\mathbf{0 . 0 0 0 3}$ & $\mathbf{0 . 0 0 0 3}$ & $\mathbf{0 . 0 0 0 4}$ & \\
\hline
\end{tabular}


Table 3. SIMPER analysis of intra-site substrate attachment at Ballyreagh, Greyabbey, NSC and Ringhaddy. The categories which contributed most to oyster attachment are listed below in rank importance; data were standardised and fourth root transformed.

\begin{tabular}{l|llll}
\cline { 2 - 5 } & Ballyreagh & Greyabbey & NSC & Ringhaddy \\
\cline { 2 - 5 } Substrate & Av. Similarity & Av. Similarity & Av. Similarity & Av. Similarity \\
& 61.74 & 71.56 & 73.28 & 70.42 \\
\cline { 2 - 5 } & Av.Sim & Av.Sim & Av.Sim & Av.Sim \\
\hline Mytilus edulis & 34.27 & 22.59 & 28.55 & 11.27 \\
Ostrea edulis & 16.11 & 14.47 & 21.99 & 18.88 \\
Unknown & 4.12 & 19.08 & 15.23 & 19.74 \\
\hline
\end{tabular}

Table 4. SIMPER displaying highest av. dis. of attachment Ballyreagh and Ringhaddy $=49.95$. The lowest $a v$. dis. of attachment was between Greyabbey and NSC $=28.94$.Substrate categories which contributed most to the differences are listed below in rank importance.

\begin{tabular}{l|lllll}
\hline Species & Ballyreagh & Ringhaddy & Species & Greyabbey & NSC \\
& Av.Abund & Av.Abund & & Av.Abund & Av.Abund \\
\hline Unknown & 0.44 & 1.03 & Pebble & 0.64 & 0.33 \\
Modiolus modiolus & 0.00 & 0.54 & Ceratoderma edule & 0.31 & 0.43 \\
Pecten maximus & 0.00 & 0.51 & Heteranomia squamula & 0.36 & 0.18 \\
Mimachlamys varia & 0.09 & 0.53 & Littorina littorea & 0.29 & 0.00 \\
Pebble & 0.31 & 0.46 & Unknown & 0.95 & 0.78 \\
Mytilus edulis & 1.15 & 0.78 & Ostrea edulis & 0.86 & 0.91 \\
\hline
\end{tabular}


Table 5. Pairwise post-hoc analysis between sites and $\%$ cover $/ \mathrm{m}^{2}$ of $M$. edulis and O. edulis shell substrate. Bold text highlights $p$ values with a statistical significant difference.

\begin{tabular}{l|llll} 
Site & Ballyreagh & NSC & Greyabbey & Ringhaddy \\
\hline Ballyreagh & & $\mathbf{0 . 0 0 0 6}$ & 0.4047 & $\mathbf{0 . 0 0 0 3}$ \\
NSC & $\mathbf{0 . 0 0 0 6}$ & & $\mathbf{0 . 0 0 3 2}$ & $\mathbf{0 . 0 0 0 2}$ \\
Greyabbey & 0.4047 & $\mathbf{0 . 0 3 3 2}$ & & $\mathbf{0 . 0 0 0 4}$ \\
Ringhaddy & $\mathbf{0 . 0 0 0 3}$ & $\mathbf{0 . 0 0 0 2}$ & $\mathbf{0 . 0 0 0 4}$ & \\
\hline
\end{tabular}

